\title{
Presentation of the Extended Technology Acceptance Model in Sports Organizations
}

\author{
${ }^{1}$ Sardar Mohammadi ${ }^{*}$ Omid Isanejad \\ ${ }^{1}$ Department of Sport Management, Faculty of Sport Sciences, University of Kurdistan, Sanandaj, Iran. ${ }^{2}$ Department of \\ Counseling, Faculty of Humanistic Sciences, University of Kurdistan, Sanandaj, Iran.
}

\begin{abstract}
Background. In recent decades, information technology has become a vital component of various aspects of our lives. The use of information technology in different domains has made the analysis of the level of its acceptance/rejection a significant factor in organizations. Objectives. The aim of this study was to illustrate the application of the extended technology acceptance model in sports organizations. Methods. The participants consisted of 350 employees selected from across various Iranian sports organizations. The data were collected according to the perceived ease of use, perceived usefulness, attitude (AT), intention to use (IU), technology self-efficacy (TSE), technology anxiety, perceived enjoyment, and user satisfaction for each variable in the study model. A panel of experts determined the face and content validity of the experiment. The Cranach's alpha coefficient was used to determine the validity. Results. The results showed that AT, self-efficacy, PU, EOU, and user satisfaction have a meaningful effect on the intention to use information technology. The highest effect was related to AT, and the lowest to user satisfaction. Conclusion. It can be claimed that when people have a more positive AT toward the use of information technology, they will exhibit beliefs or excitements, which makes it more viable for them to perceive information technology positively, and consequently increase the intention to use it.
\end{abstract}

KEY WORDS: Technology Acceptance, Sports Organizations, Employees, User Satisfaction.

\section{INTRODUCTION}

Several questions arise while considering the acceptance of information technology. Which factor/s persuade an individual to accept a new technology? Are these factors dependent on the characteristics of the technology? Do the characteristics of the individuals affect their acceptance? If any of these factors are significant, how and in what ways do they affect the acceptance of technology? Acceptance is the best action for an individual when it comes to adapting to the use of information technology. Acceptance is considered when a user accepts a new idea and practices it. The use of information technology has been observed to have grown at a fast rate across various organizations in the last two decades since a large part of information management systems studies were focused on the various factors that influence the acceptance behavior and usage of a technology in organizational environments, especially in the educational sector (1). It has resulted in the formation of different conceptual models in this domain among which the technology

*. Corresponding Author:

Sardar Mohammadi

E-mail: sardarmohammadii@gmail.com 
acceptance model (TAM) can be mentioned as a significant example.

Davis designed the TAM based on the theory of reasoned action (TRA) for modelling the user's acceptance of information technology systems (2). The present study used the TRA model developed by Ajzen and Fishbein as a framework to explain its components $(1,3-5)$.

TAM illustrates the behavior of people in connection with the usage of computers and various computer technologies. This model is useful for the prediction and explanation of user behaviors; it is a model designed for individuals (5). Therefore, this model: 1) investigates the factors related to individuals, 2) has been employed in different studies in various countries, and 3) has been analyzed in previous studies on the efficacy of its application $(6,7)$. TAM provides an explanation for the acceptance of information technology among people, the ability to clarify the user's behavior during the time s/he spends on the computer, and the number of users; however, it has often been theoretically modified and adjusted to serve a specific purpose $(8,9)$. Hence, this model was used in the present study.

The basis of TAM is formed by two special ideas or views, which are among the main factors related to the acceptance of information technology $(2,10)$ : The first idea is the perceived usefulness (PU), which is the perception of the usefulness of a system, wherein the system is regarded as useful and practical according to extent to which it can improve their performance in the organization. The PU determines the user's intention to use technology, and the attitude toward its usage. The second idea is the perceived ease of use (EOU), which is the perception in the user's mind regarding the ease of use of a system; the system is more practical if the effort needed to use it is lesser. The EOU directly determines the attitude toward the use of a technology, and it indirectly affects the intention to use the technology as well as indicates the attitude toward it $(1,11)$. However, there are other factors that also affect the acceptance behavior of information technology; one among these is attitude. Attitude (AT) is the positive or negative emotional state of the individual that affects his/her behavior. AT is the function of a set of beliefs; it indicates the level at which the employees consider the technology as being attractive, logical, advantageous, and pleasant (12). The AT toward the use of technology is the user's evaluation of the pleasure in using it. For instance, if an individual finds using the internet full of positive consequences then s/he will have a positive AT toward it. The AT toward the use of technology is influenced directly by the PU and EOU, and indirectly by external variables. Studies show that AT has a positive and meaningful impact on the intention to use technology (13-15).

The intention to use refers to "the role of intention in exhibiting a specific behavior", and is expected to lead to the actual use of technology. Thus, the intention to use refers to the user's probability of using or applying the technology $(14,16)$. The intention to use information technology, which is a function of positive AT toward the use of information technology and the user's perception of its PU, plays a significant role in the exhibition of the final behavior toward its usage. The relationship of AT and the intention to use indicates that users intend to perform actions or exhibit behaviors with positive consequences $(14,16-18)$. The intention to use information technology can be considered as an introduction, and a significant factor for its acceptance $(14,18,19)$.

The external variables that directly affect the PU and EOU of technology, and indirectly affect the PU $(20,21)$. Through the EOU of the technology are the technology's self-efficacy, anxiety, perceived enjoyment, and user satisfaction. Self-efficacy, as mentioned by the Bandura social cognitive theory (22), can be considered as a direct principle in determining the individual's behavior, and is defined by the individual's judgment of their facilities for organizing and performing the solutions needed for the accomplishment of certain planned operations.

The term self-efficacy quickly became noticed in special domains, such as in information technology. Technology self-efficacy refers to the users' conviction toward their capabilities in performing their special duties with the help of technology; it is an indicator of the individual's judgment of his/her own abilities to use the technology (23). The findings of Ramayah, Aafaqi, and Ignatius regarding the influence of computer self-efficacy showed that it has a direct impact on the EOU, and an indirect effect on the 
PU depending on the EOU (24). Some studies have shown that self-efficacy can strengthen the AT toward using technologies, such as the internet (17). In addition, computer self-efficacy has a direct effect on the AT toward its usage. Generally, it is predicted that high levels of technology self-efficacy lead to high levels of acceptance toward the use of information technology (25).

Technology self-efficacy is certainly not the only effective external factor responsible for the acceptance of technology. Other external factors may also be effective on the two variables of TAM; technology anxiety is one of these variables.

When users interact with computers, they often experience emotional states like failure, distress, anger, anxiety, and fear. In the other words, they exhibit technology anxiety. Technology anxiety is a sort of emotional and cognitive reaction that the individual feels while using information technology; it occurs mostly when the person perceives information technology as a threat. Computer anxiety can be defined as the state of the individual when s/he experiences a level of discomfiture while using a computer (19). In has been observed that employees who regularly use new technologies experience a lower level of anxiety.

From the viewpoint of Saadé and Kira, computer anxiety is the concept of specific anxiety, which is an emotion that originates from the interaction of the individual and information technology $(20,26)$. Some researchers find computer anxiety to be a key factor that influences the AT toward various forms of technology (27) including computer usage (28). Other researchers have claimed that a high level of anxiety exhibited while using the computer results in a decrease in the AT toward the use of technology (29). Computer anxiety had a direct impact on the AT toward using information technology, and led to a negative EOU. In Saade \& Kira's study, computer anxiety had a direct influence on the EOU of the computer and its PU (20).

Perceived enjoyment is another significant variable of the TAM. It is a reaction in which the individual perceives the use of a computer only for his/her own sake while not considering its instrumental value as a personal enjoyment (30).
Some researchers report that perceived enjoyment is the key factor in determining the behavioral intention (30-33) and the EOU and computer enjoyment were the basic factors that determine the behavioral intention of the user Venkatesh indicated that the effect of the EOU is determined by the directness of the users' experiences toward the system (19). The findings of Venkatesh, Speier, and Morris indicated that enjoyment has no direct effect on the behavioral intention by virtue of the EOU and PU of the computer. The aforementioned findings express the idea that the EOU is influenced by the level at which the individuals find using a computer enjoyable. In addition, they introduced enjoyment as the determining factor for the EOU; however, they ignored their relationships (34). Nah, Zhao, and Zhu showed that the perceived enjoyment was the determining factor of the PU of cellphone usage (35). According to the theory of self-efficacy, there is a positive relationship between the internal stimulation (for instance, the perceived enjoyment) and the $\operatorname{EOU}(22,36)$.

The effect of user satisfaction on his/her intention to use information technology is among the significant issues that has not often been mentioned in previous studies. User satisfaction refers to his/her AT toward information technology in the surrounding environment. Doll and Torkzadeh defined user satisfaction as "the AT of the user regarding information technology or a special computer program" (37). Moreover, Seddon and Kiew defined user satisfaction as "the satisfaction or dissatisfaction caused by all the advantages that users hope to gain while interacting with information systems"(38). User satisfaction is considered as the main factor for determining the intention to use new technologies $(39,40)$. Delone and Mclean claimed that user satisfaction can be strengthened if the performance of the individual, group, or organization improves after using the system (41). In addition, they chose user satisfaction as an attitudinal variable, which relates user satisfaction to two variables - the intention to use, and the real use (42-45). The findings of Yoojung, Hyung and Park, et al. also indicate that the PU and user satisfaction have a positive impact on the intention to use information technology $(15,32$, 46). 
Recently TAM was used to explain the process of technology acceptance(3). This model, in domains like trading(47-49), or the ICTs in the organizations $(50,51)$ is popular. However, there are instances in the domains of health $(21,52-54)$ and education(53, 54). As mentioned in the aforementioned studies, TAM has been examined in different studies. This shows that the capability of this model in interpreting the AT toward using information systems is better than the others. Many studies consider using information systems as the rate of user acceptance $(1,18,55,56)$. Therefore, the present study seeks to explore the internal relationships between technology self-efficacy, technology anxiety, perceived enjoyment and user satisfaction with structures of TAM in Iranian sports organizations in the conceptual model (Figure 1).

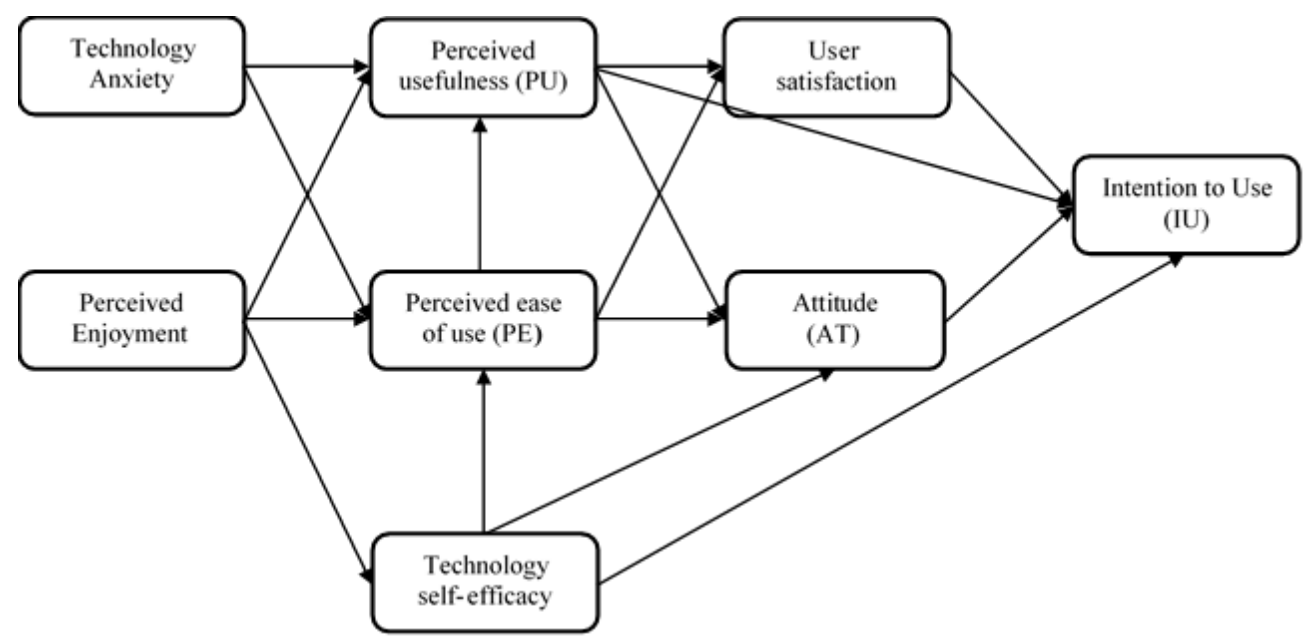

Figure 1. Conceptual model of Extended TAM

\section{MATERIALS AND METHODS}

Research design. The present study has used structural equation modeling developed by Amos to analyze the causality, and examine the hypothesis among the study variables. Data was collected through a self-reporting questionnaire that included demographic questions, and standard questionnaires for each variable in the study model.

Participants. Kline suggested that a sample size of 200 people or more is needed for complex models. He also recommended that for multivariate researches (such as SEM) the sample size should be several times (preferably 10 times) larger than the number of the variables presented in the study (57). Based on Hu and Bentler's study, for each variable in the model, a sample size of at least 15 people was needed (58), therefore, the least number for the sample of the present study was 120 . Considering the risk of loss and irrelevant data, the sample was taken as 350 employees of sports organizations $(\mathrm{N}=700)$, among them 332 numbers could be graded (Table 1 ).

Table 1. Demographic features of the participants

\begin{tabular}{|c|c|c|c|}
\hline \multicolumn{2}{|c|}{ Variable } & Number & Percent \\
\hline \multirow{2}{*}{ Gender } & Man & 124 & 37.3 \\
\hline & Woman & 208 & 62.7 \\
\hline \multirow{4}{*}{ Age } & Lower than 30 & 30 & 0.09 \\
\hline & $31-40$ & 146 & 0.44 \\
\hline & $41-50$ & 128 & 0.38 \\
\hline & More than 50 & 28 & 0.08 \\
\hline \multirow{3}{*}{ Education } & Associate & 26 & 0.02 \\
\hline & B.A & 174 & 0.52 \\
\hline & M.A \& PhD & 132 & 0.40 \\
\hline
\end{tabular}


Table 1. continued

\begin{tabular}{cccc}
\hline & Variable & Number & Percent \\
\hline & Lower than 5 & 68 & 0.21 \\
& $6-10$ & 90 & 0.27 \\
Work experience & $11-15$ & 50 & 0.15 \\
& $16-20$ & 72 & 0.22 \\
& $21-25$ & 44 & 0.13 \\
& More than 25 & 8 & 0.02 \\
\hline \multirow{2}{*}{ Having desktop computer } & Yes & 220 & 0.66 \\
& No & 112 & 0.34 \\
\hline \multirow{5}{*}{ How often to use computer } & Never & 4 & 0.01 \\
& Sometimes & 48 & 0.14 \\
& Tess than once a moth & 34 & 0.10 \\
& Once a week & 30 & 0.09 \\
& Ono three times a week & 142 & 0.43 \\
& One day off & 16 & 0.05 \\
Hours using computer & Everyday & 58 & 0.17 \\
\hline & Almost none & 22 & 0.07 \\
& Less than half an hour & 32 & 0.10 \\
& $0.5-1$ & 62 & 0.19 \\
& $1-3$ & 78 & 0.23 \\
& $3-5$ & 64 & 0.19 \\
& More than 5 & 74 & 0.22 \\
\hline
\end{tabular}

Instruments. In order to employ the research model appropriately, adjusted questionnaires from valid sources were used (Table 2). The positive point of using such scales is that they have a complete face and content validity, and provide appropriate theoretical bases for evaluations in the research domain. At first, the questionnaires were translated into Farsi by an expert of the English language, and then another person who was not aware of the process translated them into English again. Finally, after comparing the original and the translated questionnaires, followed by detecting and removing the ambiguities, the preliminary study was conducted on a sample size of 50 employees of sports organizations. After implementing their feedback, the final questionnaire consisting of 35 items was designed. There were 8 scales in this questionnaire, which ranged from 1 (completely disagree) to 5 (completely agree) based on the experts' ideas.

Table 2. Questions and sources of the questionnaire and validity

\begin{tabular}{|c|c|c|c|}
\hline structures & questions & sources & validity \\
\hline $\begin{array}{l}\text { Perceived } \\
\text { ease of use } \\
(\mathrm{PE})\end{array}$ & $\begin{array}{l}\text { Using different forms of IT in the organization } \\
\text { made ... } \\
\text { Learning how to use them easy. } \\
\text { It do whatever the employee wants. } \\
\text { Doing things easy for the user. } \\
\text { The fulfillment of the employee's job needs easy. } \\
\text { It easy to become professional in using them. } \\
\text { Using IT easy. }\end{array}$ & $(2,7,10,15)$ & 0.85 \\
\hline $\begin{array}{l}\text { Perceived } \\
\text { usefulness } \\
\text { (PU) }\end{array}$ & $\begin{array}{l}\text { I believe that using IT in the organization ... } \\
\text { Causes acceleration in doing duties. } \\
\text { Causes a better quality. } \\
\text { Increase the efficiency. } \\
\text { Makes the accomplishing the goals easy. } \\
\text { Causes an ease in doing duties. } \\
\text { Is useful for doing duties. }\end{array}$ & $(2,7,10,15)$ & 0.90 \\
\hline
\end{tabular}


Table 2. continued

\begin{tabular}{|c|c|c|c|}
\hline structures & questions & sources & validity \\
\hline Attitude (AT) & $\begin{array}{l}\text { I believe that using IT } \ldots . \\
\text { Is good. } \\
\text { Is logical. } \\
\text { Is lovely. } \\
\text { Is pleasant. } \\
\text { Is useful. }\end{array}$ & $(2,10,15,17,59,60)$ & 0.81 \\
\hline $\begin{array}{l}\text { Intention to } \\
\text { Use (IU) }\end{array}$ & $\begin{array}{l}\text { I want to use IT ... } \\
\text { For doing my responsibilities. } \\
\text { Permanently. } \\
\text { In my office. } \\
\text { Even in the future. } \\
\end{array}$ & $(2,7,10,15,31)$ & 0.89 \\
\hline $\begin{array}{l}\text { Technology } \\
\text { Self-efficacy } \\
\text { (TSE) }\end{array}$ & $\begin{array}{l}\text { I can use IT for doing my responsibilities. } \\
\text { I can use IT as an educational instrument without any } \\
\text { help. } \\
\text { I can design activities for IT without any help. }\end{array}$ & $(7,59,60)$ & 0.92 \\
\hline $\begin{array}{l}\text { Technology } \\
\text { Anxiety }\end{array}$ & $\begin{array}{l}\text { Working with IT makes me angry. } \\
\text { If I delete a huge amount of information mistakenly, I } \\
\text { become angry. } \\
\text { If I make a mistake that cannot correct, while using IT, } \\
\text { I become angry. } \\
\text { IT is somehow anxiety-ridden. }\end{array}$ & $(7,31)$ & 0.86 \\
\hline $\begin{array}{l}\text { Perceived } \\
\text { Enjoyment }\end{array}$ & $\begin{array}{l}\text { Using IT is highly enjoyable. } \\
\text { Using IT is entertaining. } \\
\text { I love using IT. } \\
\text { I enjoy all parts of my job which need using IT. }\end{array}$ & $(15,32-34,61,62)$ & 0.87 \\
\hline $\begin{array}{c}\text { User } \\
\text { satisfaction }\end{array}$ & $\begin{array}{l}\text { I think I made the right decision that was using IT in } \\
\text { the organization. } \\
\text { Experiencing using IT is pleasing for me. } \\
\text { Generally, I am satisfied with the services of IT in the } \\
\text { organization. }\end{array}$ & $(15,38,39,46,63,64)$ & 0.83 \\
\hline
\end{tabular}

Statistical Analysis. The face validity and content validity were determined by the ideas of the experts, and the validity was determined by the use of Cranach's alpha. For data analysis and fitness test of the model, the Amos 21 and SPSS 21 software were used.

\section{RESULTS}

Table 3 shows the descriptive features and correlation matrix of the study variables. The highest correlation for user satisfaction and perceived enjoyment was $(r=0.79)$, and the lowest was $(r=0.002)$, which indicated the relation between computer anxiety and the intention to use.

Table 4 shows the indicators of the model fitness. The GFI and AGFI are higher than 0.9, and $\mathrm{X}^{2} / \mathrm{DF}=3.657$, which indicate that the model has an appropriate fitness.
The findings of the study are shown in Figure 1. They indicate that the highest direct effect is related to the effect of perceived enjoyment on the PU $(\beta s=0.665)$, and the lowest rate is related to the effect of computer anxiety on the EOU $(\beta s=$ 0.099).

\section{DISCUSSION}

The aim of the present study was to analyze the structural relationships of the TAM variables, such as PU, EOU, AT toward the use, intention to use information technology along with external factors (such as self-efficacy of using IT, technology anxiety, perceived enjoyment), and user satisfaction as the mediator variable.

The findings of this study demonstrated the direct and indirect effects of the self-efficacy of the technology, perceived enjoyment of its usage, technology anxiety, and user satisfaction 
on the intention to use information technology. The presented model confirms the basic relationships of the stimulating variables, psychological and social variables, and the significant variables of TAM from different aspects.

Table 3. Descriptive features and correlation matrix of the study variables

\begin{tabular}{|c|c|c|c|c|c|c|c|c|}
\hline & 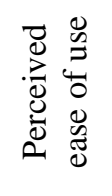 & 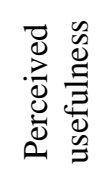 & $\begin{array}{l}\text { 总 } \\
\text { 总 }\end{array}$ & 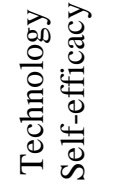 & 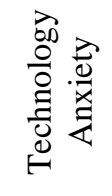 & 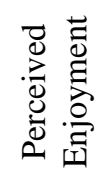 & 岕. & $\mathrm{M} \pm \mathrm{ds}$ \\
\hline Perceived ease of use & 1 & & & & & & & $10.13 \pm 2.80$ \\
\hline Perceived usefulness & $.645^{* *}$ & 1 & & & & & & $8.98 \pm 2.89$ \\
\hline Attitude & $.527^{* *}$ & $.485^{* *}$ & 1 & & & & & $6.95 \pm 2.32$ \\
\hline Technology Self-efficacy & $.221^{* *}$ & $.131^{*}$ & $.305^{* *}$ & 1 & & & & $9.72 \pm 2.61$ \\
\hline Technology Anxiety & -.086 & -.085 & $-.171^{* *}$ & -.059 & 1 & & & $47.07 \pm 7.71$ \\
\hline Perceived Enjoyment & $.280^{* *}$ & $.395^{* *}$ & $.318^{* *}$ & $.171^{* *}$ & $-.144^{* *}$ & 1 & & $2.94 \pm 1.50$ \\
\hline User satisfaction & $.359^{* *}$ & $.408^{* *}$ & $.392^{* *}$ & $.136^{*}$ & $-.121^{*}$ & $.79 * *$ & 1 & $8.68 \pm 2.89$ \\
\hline Intention to Use (IU) & $.598^{* *}$ & $.491^{* *}$ & $.687^{* *}$ & $.474^{* *}$ & .002 & $.230^{* *}$ & $.340^{* *}$ & $9.87 \pm 2.54$ \\
\hline
\end{tabular}

Table 4. Indicators of the model fitness

\begin{tabular}{cccccccc}
\hline $\mathrm{X}^{2}$ & DF & $\mathrm{X}^{2} / \mathrm{DF}$ & GFI & AGFI & CFI & RMSEA & TLI \\
\hline 25.599 & 7 & 3.657 & 0.98 & 0.91 & 0.98 & 0.09 & 0.94 \\
\hline
\end{tabular}

Table 5. Direct, indirect and total effects of model 1 none standardized

\begin{tabular}{|c|c|c|c|}
\hline \multirow[t]{2}{*}{ Path } & \multicolumn{3}{|c|}{ Nonstandard } \\
\hline & Indirect effects & Direct effects & Total effects \\
\hline Technology anxiety $\rightarrow$ PE & 0.000 & $-0.036 * *$ & -0.036 \\
\hline Technology anxiety $\rightarrow$ AT & -0.012 & $-0.036 * *$ & -.048 \\
\hline Technology self-efficacy $\rightarrow$ PE & 0.000 & $0.197 * *$ & 0.197 \\
\hline Technology self-efficacy $\rightarrow$ AT & 0.066 & $0.189 * *$ & 0.255 \\
\hline Technology self-efficacy $\rightarrow$ IU & 0.152 & $0.296 * *$ & 0.448 \\
\hline $\begin{array}{l}\text { Perceived enjoyment } \rightarrow \text { technology self- } \\
\text { efficacy }\end{array}$ & 0.000 & $0.551 * *$ & 0.551 \\
\hline Perceived enjoyment $\rightarrow$ PE & 0.108 & $1.953 * *$ & 2.061 \\
\hline Perceived enjoyment $\rightarrow$ PU & 0.818 & $3.614 * *$ & 4.432 \\
\hline $\mathbf{P E} \rightarrow \mathbf{P U}$ & 0.000 & $0.397 * *$ & 0.397 \\
\hline $\mathbf{P E} \rightarrow \mathbf{A T}$ & 0.079 & $0.259 * *$ & 0.338 \\
\hline PE $\rightarrow$ user satisfaction & 0.109 & $0.228 * *$ & 0.337 \\
\hline $\mathbf{P E} \rightarrow \mathbf{I U}$ & 0.236 & $0.155 * *$ & 0.391 \\
\hline $\mathbf{P U} \rightarrow \mathbf{A T}$ & 0.000 & $0.199 * *$ & 0.199 \\
\hline PU $\rightarrow$ user satisfaction & 0.000 & $0.274 * *$ & 0.274 \\
\hline $\mathbf{P U} \rightarrow \mathbf{I U}$ & 0.108 & $0.168 * *$ & 0.276 \\
\hline $\mathbf{A T} \rightarrow \mathbf{I U}$ & 0.000 & $0.396 * *$ & 0.396 \\
\hline User satisfaction $\rightarrow$ IU & 0.000 & $0.106 * *$ & 0.106 \\
\hline
\end{tabular}




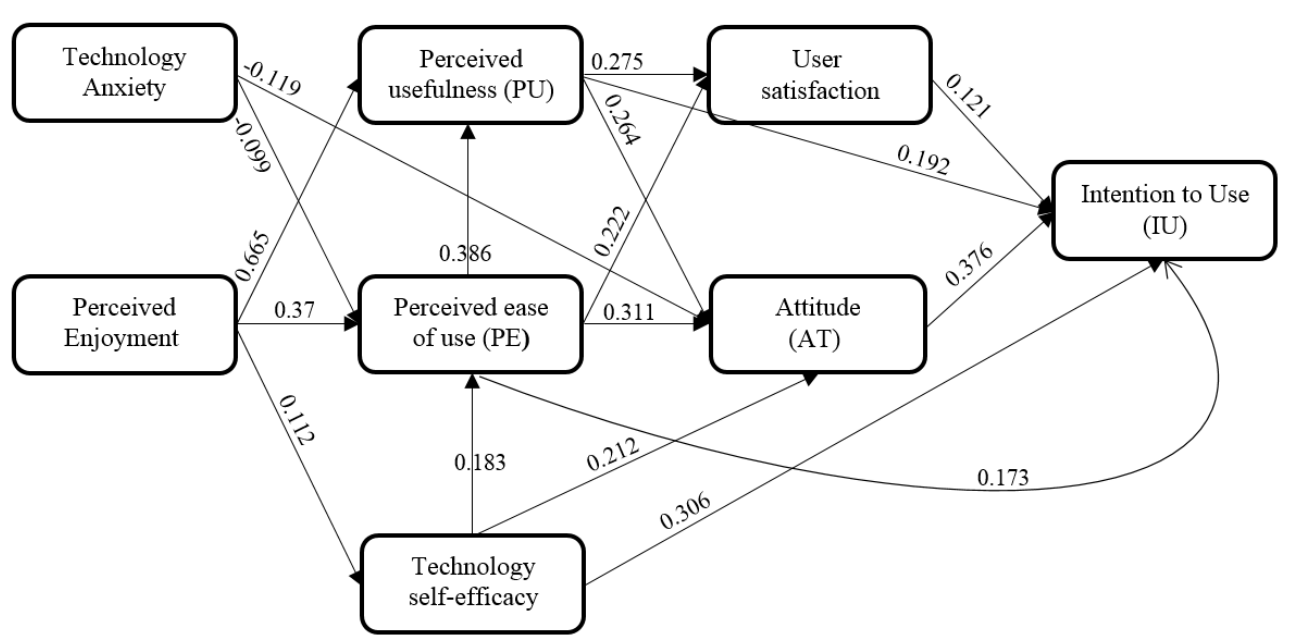

Figure 2. Standard path correlation

The findings of this study demonstrated that self-efficacy has a direct effect on the EOU. The results of the previous studies $(24,65-67)$ indicate that the self-efficacy of technology is the determining factor of the EOU, which corresponds with the results of the present study. However, no meaningful effects were observed in the studies by Rezaei, et al., 2008 (68). In some studies, it was determined that the self-efficacy of using information technology is the key factor in its usage, which is in agreement with the results of the present study $(56,65,68-71)$. The findings demonstrated the direct effect of self-efficacy on the AT toward the use of information technology. These findings go along with the results of the study by Sanchez Prieto, J.C Olmos, Chun-Hua Hsiao, and Kai-Yu Tong (2015), which indicated that self-efficacy is a stimulating variable having an impact on the AT toward the use of information technology. They also stated that self-efficacy is one of the variables that should be considered as significant in the use of technology. These findings indicate that if the users' conviction toward their ability to use information technology is positive then it is easier for them understand information technology better, which will increase the probability of their usage. Therefore, the effect of the individuals' judgment regarding their own abilities while using information technology (through EOU and AT) on their beliefs leads to the probability of the use of information technology. This, in turn, results in a better performance.

The findings of the present study demonstrated that the perceived enjoyment has a direct and meaningful effect on the main structures of TAM (EOU and PU) and self-efficacy. The direct effect of the perceived enjoyment is also meaningful as shown in the studies by Yi \& Hwang, and Ahmadi Dehghotbi $(32,70)$. Therefore, people should be able to judge their own abilities to effectively use a computer more positively when they perceive information technology as useful, regardless of its instrumental applications. In (15, 31-33, 56, 72-74) previous studies, the perceived enjoyment was the determining factor on EOU and PU of information technology. Theoretically speaking, the entertainment feature of information technology used in sports organizations acts as the main enjoyment factor, and results in an easier understanding of information technology for the users. In addition, the innovations offered by information technology make it more exciting for them. Therefore, entertainment, pleasure, and excitement (enjoyment factors) lead to a higher acceptance of technology. In addition, excitement and pleasure of information technology provide users with the feeling that they have a considerable control over their activities, and thus, they can do things faster and more efficiently. Therefore, they perceive information technology as a useful tool.

The findings of this study indicated that technology anxiety had a negative and meaningful effect on the EOU and AT. Therefore (based on Fig. 2), it can be concluded that technology anxiety has a decreasing effect on the TAM, and it seems that it acts as a deterrent to technology acceptance. The results of (27) and (75) showed Higher points in anxiety lead to negative AT, and lower EOU of 
information technology, thus leading to a lower use of information technology. The findings of the present study affirm the same points. Whenever computer usage is accompanied with fear and anxiety, the usage of technology becomes less efficient, and hence, the employees' performance will be adversely affected in the organization (20), The findings indicated that there is a negative and meaningful relationship between computer anxiety and the ease of use. However, in (76), and (68), the impact of computer anxiety on the EOU was not meaningful, which corresponds with the present study. It seems that feeling threatened in using information technology can lead to a negative AT; the individual may think that s/he is not sufficiently knowledgeable in the use of information technology leading to a feeling of disinterest toward the use of technology. The more people feel anxious about using the computer, the more difficult will be their perception along with lesser belief in their abilities, and thus, a lower the intention to use technology, and vice versa.

The findings of the model indicated that user satisfaction plays a significant part in predicting and raising the intention of the individual to use information technology $(15,39,40,64,77-80)$, it has a meaningful impact on the behavioral intention to use communication services in the long term. Lee \& Kim claimed that user satisfaction can be considered as the main factor in predicting the intention to use a technology (81). Battacherjee also stated that the satisfaction, which is takes form during the initial usage of a technology, has a positive effect on instilling a permanent intention to use the system (43). The findings of Liaw et al. showed that user satisfaction is to be considered as the main factor in predicting the intention to use a computer. Since the impact of AT and self-efficacy on the intention to use information technology was found to be higher than user satisfaction, these findings need to be confirmed practically in the future studies (69).

\section{CONCLUSION}

The findings of the model showed AT, selfefficacy, PU, EOU and user satisfaction have respectively a meaningful effect on the intention to use information technology. The highest effect was related to AT and the lowest one to satisfaction. Theoretically speaking, AT is a combination of beliefs and excitements which prepare the individual to observe different phenomena positively or negatively in advance. AT summarizes the evaluations of phenomena and therefore is responsible for the prediction and guidance of the future actions or behaviors. In the present study higher points in AT represent a more positive AT. Thus, it can be claimed that as far as people have a more positive AT toward information technology, they will experience beliefs or excitements which make them prepared to perceive information technology positively and have the intention to use it.

The present model is related to a complex behavioral phenomenon and definitely has shortcomings like any other models. Thus, it is worth it to investigate the extension of the other stimulating variables on the model for the future studies.

Users' reactions were not examined several times, since the study was conducted in a single step. To be more meticulous, more accurate experimental studies are needed in this domain.

The lack of homogenous results and background about the relationships between external variables, especially among technology self-efficacy, technology anxiety and perceived enjoyment with TAM structures and their inner relationships is the other point to be mentioned.

\section{APPLICABLE REMARKS}

- The AT, self-efficacy, PU, and EOU have the most and user satisfaction have the least effect on the decision to use the information technology.

- It is suggested that sports organization for increasing its productivity and efficiency not only emphasize to information technology but make it proportional to organization's need.

- Because of the most effect of AT on intention to use IT, it suggests that these organizations do their plans for creating a positive attitude on acceptance of information technology. This leads to make it easy and user satisfaction's reinforcement information technology in the organization. 


\section{REFERENCES}

1. Wallace LG, Sheetz SD. The adoption of software measures: A technology acceptance model (TAM) perspective. Information \& Management. 2014;51(2):249-59.

2. Davis FD. User acceptance of information technology: system characteristics, user perceptions and behavioral impacts. International journal of man-machine studies. 1993;38(3):475-87.

3. Lee Y-C. An empirical investigation into factors influencing the adoption of an e-learning system. Online Information Review. 2006;30(5):517-41.

4. Bagozzi RP. The legacy of the technology acceptance model and a proposal for a paradigm shift. Journal of the association for information systems. 2007;8(4):3.

5. Lu Y, Zhou T, Wang B. Exploring Chinese users' acceptance of instant messaging using the theory of planned behavior, the technology acceptance model, and the flow theory. Computers in Human Behavior. 2009;25(1):29-39.

6. Chang S-H, Chou C-H, Yang J-M, editors. The Literature Review of Technology Acceptance Model: A Study of the Bibliometric Distributions. PACIS; 2010.

7. Sánchez-Prieto JC, Olmos-Migueláñez S, García-Peñalvo FJ. Informal tools in formal contexts: Development of a model to assess the acceptance of mobile technologies among teachers. Computers in Human Behavior. 2016;55:519-28.

8. Huijts NM, Molin E, Steg L. Psychological factors influencing sustainable energy technology acceptance: A review-based comprehensive framework. Renewable and Sustainable Energy Reviews. 2012;16(1):525-31.

9. Holden H, Rada R. Understanding the influence of perceived usability and technology self-efficacy on teachers' technology acceptance. Journal of Research on Technology in Education. 2011;43(4):343-67.

10. Davis FD, Bagozzi RP, Warshaw PR. User acceptance of computer technology: a comparison of two theoretical models. Management science. 1989;35(8):982-1003.

11. Surendran P. Technology acceptance model: A survey of literature. International Journal of Business and Social Research. 2012;2(4):175-8.

12. Leonard LN, Cronan TP, Kreie J. What influences IT ethical behavior intentions-planned behavior, reasoned action, perceived importance, or individual characteristics? Information \& Management. 2004;42(1):143-58.

13. Gumussoy C, Calisir F, Bayram A, editors. Understanding the behavioral intention to use ERP systems: An extended technology acceptance model. 2007 IEEE International Conference on Industrial Engineering and Engineering Management; 2007: IEEE.

14. Guritno S, Siringoringo H. Perceived usefulness, ease of use, and attitude towards online shopping usefulness towards online airlines ticket purchase. Procedia-Social and Behavioral Sciences. 2013;81:212-6.

15. Park E, Baek S, Ohm J, Chang HJ. Determinants of player acceptance of mobile social network games: An application of extended technology acceptance model. Telematics and Informatics. 2014;31(1):3-15.

16. Ratten V. A cross-cultural comparison of online behavioural advertising knowledge, online privacy concerns and social networking using the technology acceptance model and social cognitive theory. Journal of Science \& Technology Policy Management. 2015;6(1):25-36.

17. Hsiao $\mathrm{C}-\mathrm{H}$, Tang $\mathrm{K}-\mathrm{Y}$. Investigating factors affecting the acceptance of self-service technology in libraries: The moderating effect of gender. Library Hi Tech. 2015;33(1):114-33.

18. Erasmus E, Rothmann S, Van Eeden C. A structural model of technology acceptance. SA Journal of Industrial Psychology. 2015;41(1):01-12.

19. Venkatesh V, Davis FD. A theoretical extension of the technology acceptance model: Four longitudinal field studies. Management science. 2000;46(2):186-204.

20. Saadé RG, Kira D. The emotional state of technology acceptance. Issues in informing science and information technology. 2006;3:529-39.

21. Chang PV-C. The validity of an extended technology acceptance model (TAM) for predicting intranet/portal usage. 2004.

22. Bandura A. Self-efficacy: toward a unifying theory of behavioral change. Psychological review. 1977;84(2):191.

23. Pauli KP, Gilson RL, May DR. Anxiety and avoidance: The mediating effects of computer self-efficacy on computer anxiety and intention to use computers. Review of Business Information Systems (RBIS). 2011;11(1):57-64.

24. Ramayah T, Aafaqi B, Ignatius J. Role of self-efficacy in e-library usage among students of a public university in Malaysia. Malaysian Journal of Library and Information Science. 2004;9:39-58.

25. Kripanont N. Using a technology acceptance model to investigate academic acceptance of the internet. Journal of Business Systems, Governance, and Ethics. 2006;1(2):13-28.

26. Saadé RG, Kira D. Computer anxiety in e-learning: The effect of computer self-efficacy. Journal of Information Technology Education. 2009;8(1):177-91. 
27. Alenezi AR, Karim AMA, Veloo A. An empirical investigation into the role of enjoyment, computer anxiety, computer self-efficacy and internet experience in influencing the students' intention to use e-learning: A case study from Saudi Arabian governmental universities. TOJET: The Turkish Online Journal of Educational Technology. 2010;9(4).

28. Compeau D, Higgins CA, Huff S. Social cognitive theory and individual reactions to computing technology: A longitudinal study. MIS quarterly. 1999:145-58.

29. Abubakar D, Adetimirin A. INFLUENCE OF COMPUTER LITERACY ON POSTGRADUATES'USE OF ERESOURCES IN NIGERIAN UNIVERSITY LIBRARIES. Library Philosophy and Practice. 2015:1.

30. Davis FD, Bagozzi RP, Warshaw PR. Extrinsic and intrinsic motivation to use computers in the workplace1. Journal of applied social psychology. 1992;22(14):1111-32.

31. Venkatesh V, Morris MG, Davis GB, Davis FD. User acceptance of information technology: Toward a unified view. MIS quarterly. 2003:425-78.

32. Mun YY, Hwang Y. Predicting the use of web-based information systems: self-efficacy, enjoyment, learning goal orientation, and the technology acceptance model. International Journal of Human-Computer Studies. 2003;59(4):431-49.

33. Teo T, Noyes J. An assessment of the influence of perceived enjoyment and attitude on the intention to use technology among pre-service teachers: A structural equation modeling approach. Computers \& Education. 2011;57(2):1645-53.

34. Venkatesh V, Speier C, Morris MG. User acceptance enablers in individual decision making about technology: Toward an integrated model. Decision Sciences. 2002;33(2):297-316.

35. Nah FF-H, Zhao F, Zhu W. Factors influencing users' adoption of mobile computing. Managing E-Commerce and Mobile Computing Technologies Book. 2003:260-71.

36. Bandura A. Self-efficacy mechanism in human agency. American psychologist. 1982;37(2):122.

37. Doll WJ, Torkzadeh G. The measurement of end-user computing satisfaction. MIS quarterly. 1988:259-74.

38. Seddon P, Kiew M-Y. A partial test and development of DeLone and McLean's model of IS success. Australasian Journal of Information Systems. 1996;4(1).

39. Negash S, Ryan T, Igbaria M. Quality and effectiveness in web-based customer support systems. Information \& Management. 2003;40(8):757-68.

40. Yoon Y, Guimaraes T, O'Neal Q. Exploring the factors associated with expert systems success. MIS quarterly. 1995:83-106.

41. Delone WH, McLean ER. The DeLone and McLean model of information systems success: a ten-year update. Journal of management information systems. 2003;19(4):9-30.

42. Mathieson K. Predicting user intentions: comparing the technology acceptance model with the theory of planned behavior. Information systems research. 1991;2(3):173-91.

43. Bhattacherjee A. An empirical analysis of the antecedents of electronic commerce service continuance. Decision support systems. 2001;32(2):201-14.

44. Cenfetelli R, Benbasat I, Al-Natour S. Information technology mediated customer service: A functional perspective. ICIS 2005 Proceedings. 2005:58.

45. Konradt U, Christophersen T, Schaeffer-Kuelz U. Predicting user satisfaction, strain and system usage of employee self-services. International Journal of Human-Computer Studies. 2006;64(11):1141-53.

46. Kim Y, Lee HS. Quality, perceived usefulness, user satisfaction, and intention to use: An empirical study of ubiquitous personal robot service. Asian Social Science. 2014;10(11):1.

47. Chen L, Gillenson L, Sherrell L. Enticing online consumers: an extended technology acceptance perspective, 39 (8), 709-719. doi: 10.1016. S0378-7206 (01). 2002:00127-6.

48. Gefen D, Karahanna E, Straub DW. Trust and TAM in online shopping: an integrated model. MIS quarterly. 2003;27(1):51-90.

49. Wu J-H, Wang S-C. What drives mobile commerce?: An empirical evaluation of the revised technology acceptance model. Information \& Management. 2005;42(5):719-29.

50. Hsu C-L, Lu H-P. Why do people play on-line games? An extended TAM with social influences and flow experience. Information \& Management. 2004;41(7):853-68.

51. Yang Z, Cai S, Zhou Z, Zhou N. Development and validation of an instrument to measure user perceived service quality of information presenting web portals. Information \& Management. 2005;42(4):575-89.

52. Persico D, Manca S, Pozzi F. Adapting the Technology Acceptance Model to evaluate the innovative potential of e-learning systems. Computers in Human Behavior. 2014;30:614-22.

53. Stantchev V, Colomo-Palacios R, Soto-Acosta P, Misra S. Learning management systems and cloud file hosting services: A study on students' acceptance. Computers in Human Behavior. 2014;31:612-9. 
54. Sánchez RA, Hueros AD. Motivational factors that influence the acceptance of Moodle using TAM. Computers in Human Behavior. 2010;26(6):1632-40.

55. Malhotra Y, Galletta DF, editors. Extending the technology acceptance model to account for social influence: Theoretical bases and empirical validation. Systems sciences, 1999 HICSS-32 Proceedings of the 32nd annual Hawaii international conference on; 1999: IEEE.

56. Yi-Cheng C, Yi-Chien LV, Ron-Chuen Y. Examining factors influencing behavioral intentions to use asynchronous web-based language learning. PACIS 2006 Proceedings. 2006:65.

57. Kline RB. Principles and practice of structural equation modeling: Guilford publications; 2015.

58. Hu Lt, Bentler PM. Cutoff criteria for fit indexes in covariance structure analysis: Conventional criteria versus new alternatives. Structural equation modeling: a multidisciplinary journal. 1999;6(1):1-55.

59. Tang K-Y. Investigating factors affecting the acceptance of self-service technology in libraries. Library Hi Tech. 2015;33(1):114-33.

60. Taylor S, Todd PA. Understanding information technology usage: A test of competing models. Information systems research. 1995;6(2):144-76.

61. Koufaris M. Applying the technology acceptance model and flow theory to online consumer behavior. Information systems research. 2002;13(2):205-23.

62. Lee W, Xiong L, Hu C. The effect of Facebook users' arousal and valence on intention to go to the festival: Applying an extension of the technology acceptance model. International Journal of Hospitality Management. 2012;31(3):819-27.

63. Lee KC, Chung N. Understanding factors affecting trust in and satisfaction with mobile banking in Korea: A modified DeLone and McLean's model perspective. Interacting with computers. 2009;21(5-6):385-92.

64. Park E, Del Pobil AP. Modeling the user acceptance of long-term evolution (LTE) services. annals of telecommunications-annales des télécommunications. 2013;68(5-6):307-15.

65. Jeong HI, Kim Y. The acceptance of computer technology by teachers in early childhood education. Interactive Learning Environments. 2016:1-17.

66. McFarland DJ. The Role of Age and Efficacy on Technology Acceptance: Implications for E-Learning. 2001.

67. Lopez DA, Manson DP. A study of individual computer self-efficacy and perceived usefulness of the empowered desktop information system. 1997.

68. Rezaei M, Mohammadi HM, Asadi A, Kalantary K. Predicting e-learning application in agricultural higher education using technology acceptance model. Turkish Online Journal of Distance Education. 2008;9(1).

69. Liaw S-S, Chang W-C, Hung W-H, Huang H-M. Attitudes toward search engines as a learning assisted tool: approach of Liaw and Huang's research model. Computers in Human Behavior. 2006;22(2):177-90.

70. ahmadi dehghotbi m, moshkani m, mohammad khani A. The Impact of Computer Self-efficacy and Anxiety on the Structures of Davis' TAM. The New Prospects of Social Psychology. 2010;13(1):51- 71.

71. Teo T. Modelling technology acceptance in education: A study of pre-service teachers. Computers \& Education. 2009;52(2):302-12.

72. Sun H, Zhang P. Applying markus and Robey's causal structure to examine user technology acceptance research: a new approach. JITTA: Journal of Information Technology Theory and Application. 2006;8(2):21.

73. Olmos Migueláñez S, García-Peñalvo FJ, Sánchez Prieto JC. Informal Tools in Formal Contexts: Development of a Model to Assess the Acceptance of Mobile Technologies among Teachers. 2016.

74. Al-Debei MM. The quality and acceptance of websites: an empirical investigation in the context of higher education. International Journal of Business Information Systems. 2014;15(2):170-88.

75. Adetimirin A. An Empirical Study of Online Discussion Forums by Library and Information Science Postgraduate Students using Technology Acceptance Model 3. Journal of Information Technology Education: Research. 2015;14:257-69.

76. Ifinedo P. Acceptance and continuance intention of web-based learning technologies (WLT) use among university students in a Baltic country. The Electronic Journal of Information Systems in Developing Countries. 2006;23.

77. Hadji B, Degoulet P. Information system end-user satisfaction and continuance intention: A unified modeling approach. Journal of biomedical informatics. 2016;61:185-93.

78. Kang YS, Lee H. Understanding the role of an IT artifact in online service continuance: An extended perspective of user satisfaction. Computers in Human Behavior. 2010;26(3):353-64.

79. Mohammadi H. Investigating users' perspectives on e-learning: an integration of TAM and IS success model. Computers in Human Behavior. 2015;45:359-74.

80. Ofori KS, Larbi-Siaw O, Fianu E, Gladjah RE, Boateng EOY. Factors Influencing the Continuance Use of Mobile Social Media: The Effect of Privacy Concerns. Journal of Cyber Security.4:105-24.

81. Lee H, Kim J, Kim J. Determinants of success for application service provider: An empirical test in small businesses. International Journal of Human-Computer Studies. 2007;65(9):796-815. 